\title{
Encuerpamientos. Una propuesta de abordaje posthumano de las relaciones entre cuerpo e imagen en los cruces entre arte, ciencia y tecnología ${ }^{1}$
}

\section{Artículo de investigación}

\section{Nadia Martin}

CONICET-IIAC/UNTREF, Argentina

martin.nadia@gmail.com

Recibido: 14 de mayo de 2021

Aceptado: 12 de julio de 2021

Como citar este artículo: Martin, N. (2022).

Encuerpamientos. Una propuesta de abordaje posthumano de las relaciones entre cuerpo e imagen en los cruces entre arte, ciencia y tecnología. Calle14: revista de investigación en el campo del arte. 17(31), pp. 160-177. DOI: https://doi.org/10.14483/21450706.18697 


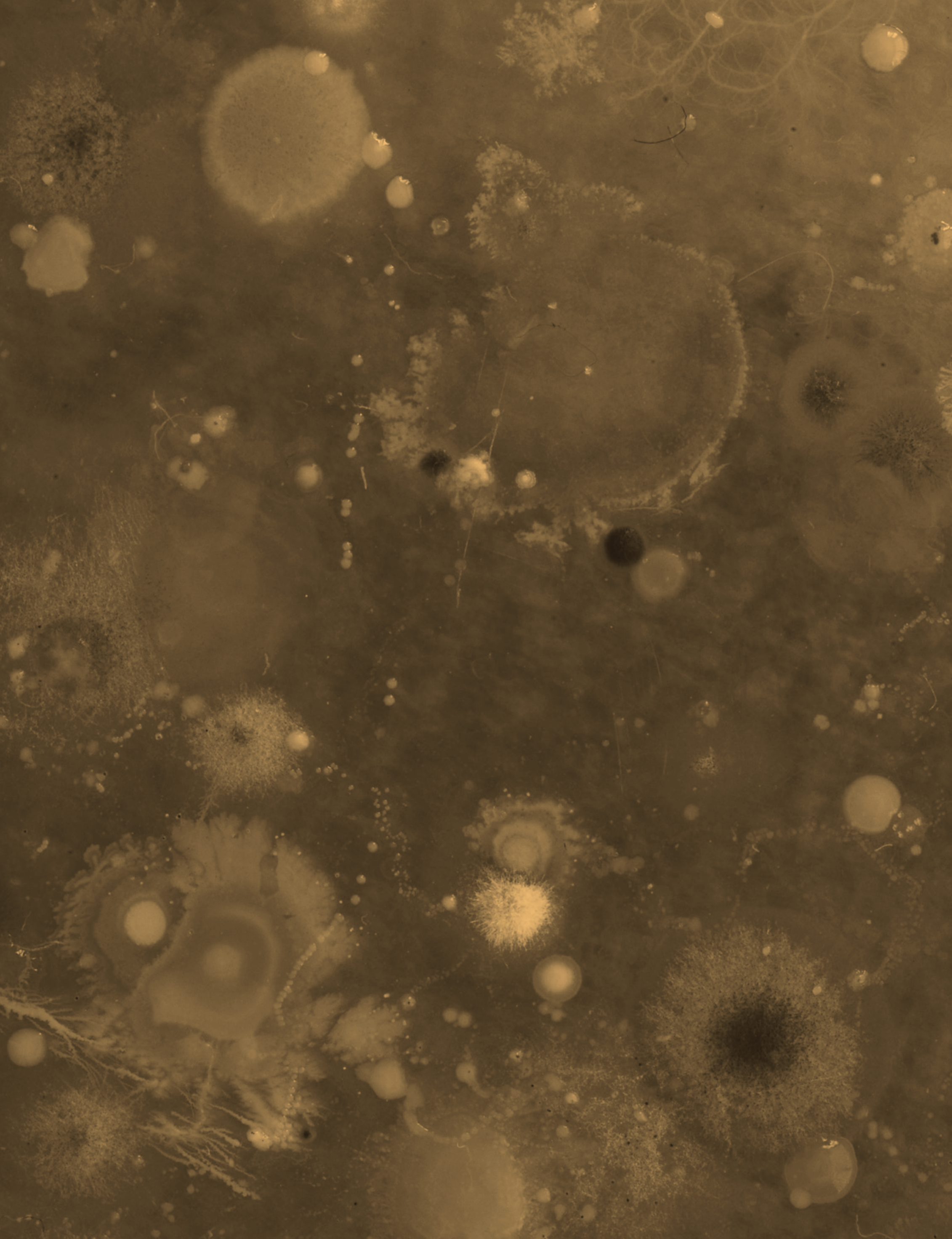


Encuerpamientos. Una propuesta de abordaje posthumano de las relaciones entre cuerpo e imagen

\begin{abstract}
Resumen
En este artículo-ensayo la noción de encuerpamiento se propone para pensar, en las intersecciones contemporáneas entre arte, ciencia y tecnología, las relaciones entre cuerpo e imagen desde una perspectiva posthumana. Lejos de los modelos abstractos y universales -como el cuerpo antropomórfico del humanismo moderno- y de las lógicas reproductivas -como las del cuerpo genético de la biomedicina contemporánea-, cada encuerpamiento es un acto creativo, difractario, que ocurre en el encuentro entre el pensamiento o especulación teórica y los casos concretos y situados dentro de las dinámicas semiótico-materiales de lo visual, en los que el mismo imaginario del cuerpo se modula.
\end{abstract}

\title{
Palabras clave
}

Arte contemporáneo; cuerpo; imagen; estudios visuales; posthumanismo.

Encuerpamiento. A proposal for a posthuman approach to the relationships between body and image

\begin{abstract}
In this article-essay, we propose a new notion of "embodiment", encuerpamiento, as a way to think about the relationships between body and image from a post-human perspective, through the contemporary intersections between art, science and technology. Far from abstract and universal models -such as the anthropomorphic body of modern humanism- and reproductive logics -such as those of the genetic body of contemporary biomedicine-, each entanglement is a creative, diffractory act that occurs in the encounter between thought or theoretical speculation and the concrete cases situated within the semiotic-material dynamics of the visual, in which the very imaginary world of the body is modulated.
\end{abstract}

\section{Keywords}

Contemporary art; body; image; visual studies; posthumanism

Encuerpamiento. Une proposition pour une approche posthumaine des relations entre le corps et l'image

\begin{abstract}
Résumé
Dans cet article-essai, nous proposons une nouvelle notion de corporisation, encuerpamiento, comme moyen de penser les relations entre le corps et l'image dans une perspective posthumaine à travers les intersections contemporaines entre l'art, la science et la technologie. Loin des modèles abstraits et universels -comme le corps anthropomorphique de l'humanisme moderne- et des logiques reproductives -comme celles du corps génétique de la biomédecine contemporaine-, chaque intrication est un acte créateur et diffractant qui se produit dans la rencontre entre la pensée ou la spéculation théorique et les cas concrets situés dans la dynamique sémiotique-matérielle du visuel, où se module le même imaginaire du corps.
\end{abstract}

\section{Mots clés}

Art contemporain ; corps ; image ; études visuelles ; post-humanisme

Encorpamentos. Uma proposta de abordagem pós-humana das relações entre corpo e imagem nos cruzamentos entre arte, ciência e tecnologia

\section{Resumo}

Neste artigo ensaio a especificação da noção de encorpamentos proposta para pensar, nas intersecções contemporâneas entre arte, ciência e tecnologia, as relações entre corpo e imagem 
a partir de uma perspectiva pós-humana. Longe dos modelos abstratos e universais- como o corpo antropomórfico do humanismo moderno- e das lógicas reprodutivas- como as do corpo genético da biomedicina contemporânea-, cada encorpamento é um ato criativo, difrativo, que ocorre no encontro entre o pensamento (a especulação teórica) e os casos concretos e situados (que implicam as dinâmicas semiótico-materiais do visual) nos quais o mesmo imaginário do corpo se modula.

\section{Palavras chave}

Arte contemporânea; Corpo; Imagem; Estudos visuais; Pós-humanismo

\section{Achka tukuspa sug nei sikangapa nukanchi kikinsina kawaringapa iskai ruraikuna Sugllapi alpapi} tariska i tecnología

\section{Maillallachiska}

Kai mailla kilkaskapi kallariku iachachinga, atun tutaska niku chasallata iuiaringapa ruraikuna apachiska chi watallapi rurai, kausai, kunauramanda kausi, rurangapa pangapi nukanchi kikinta kawachingapa. Karumandata katichispa allilla kausangapa nukanchi parla. Ambikuna Maskaspa Nukanchipa alpapi, paikuna kawankuna kikin atuniaska imasa munaskasina apachispa mana allilla iuiarispa, nispa kawaku ima ministidu ka iuianispa nukanchi kikinmanda pangapi churduia.

\section{Rimangapa Ministidukuna}

Ruraska chi watallapita; nukakin llatan,ruraska; kawangapa; iachaikui kawakunata; nukanchisina rigcha; posthumanismo 


\section{Introducción}

Las intersecciones entre arte, ciencia y tecnología, han instado a la teoría del arte a reflexionar sobre la operatividad teórico-metodológica de sus categorías tradicionales, con el fin de avanzar en la construcción de marcos conceptuales que se ajusten a las especificidades transdisciplinares - 0 incluso indisciplinadas- de estas zonas productivas. En este marco, la intención de mi escrito es avanzar en la especificación de una noción, los encuerpamientos, propuesta para pensar, en estas zonas del arte contemporáneo, las relaciones entre cuerpo e imagen desde una perspectiva posthumana.

Sabemos por Rossi Braidotti (2015) que los saberes posthumanos surgen cuando, como consecuencia de los procesos de intervención tecno-científica que vuelven porosas las fronteras humano-máquina e interespecie, los debates entre humanismo y antihumanismo iniciados en los años sesenta se apaciguan. ${ }^{2}$ Consisten, así, en un campo de inflexión teórica que comienza a pensar las relaciones entre lo vivo y lo inerte, y entre lo humano y lo no humano bajo la idea del continuum, como complejos ensamblajes naturoculturales (Latour, 2012; Haraway, 1995). También sabemos que "posthumanismo" se ha convertido en un "concepto paragüas" en el que se incluyen las más diversas perspectivas analíticas, objetos de estudio y zonas problemáticas (Ferrando, 2019). Quisiera, por ello, dejar en claro de antemano que si bien en este caso considero parte de los saberes posthumanos a las perspectivas

1 Este escrito surge de mi trabajo de investigación doctoral sobre imaginarios corporales posthumanos en los cruces contemporáneos entre arte, ciencia y tecnología. El mismo constituye un aporte que desarrollo con mayor profundidad en mi tesis, hoy en proceso de escritura y próxima a ser entregada, para optar por el título de Doctorado en Teoría Comparadas de las Artes de la Universidad Nacional de Tres de Febrero (UNTREF). Estos estudios, por su parte, se han llevado a cabo en el marco de una Beca Interna de Doctorado otorgada por el Consejo Nacional de Investigaciones Científicas y Técnicas (CONICET).

2 Vale destacar que una crítica lapidaria al humanismo moderno -y a la connivencia ideológica de las disciplinas humanísticas - se articuló desde los años '70 en el postestructuralismo francés. Por su parte, vale agregar, desde los años ' 70 y ' 80 s, los movimientos descoloniales y los feminismos ejercieron una devastadora deconstrucción de las categorías identitarias abstractas, universales, basadas en relaciones de oposición binaria estructurantes de las jerarquías ontológicas. En este marco, "el humano" (identificado con el modelo masculino, blanco, heterosexual, europeo, etc) habría arrojado al campo de lo "diferente" —entendiendo la diferencia en términos peyorativos- a mujeres, negrxs, indígenas, disidencias sexuales, etc.; pero también a animales no humanos, plantas, territorios y otros planos de lo viviente y lo no viviente convertido en mero recurso. enmarcadas en los nuevos materialismos (Coole y Frost, 2012; etc), al realismo especulativo y la ontología orientada a objetos (Meilassoux, 2015; Harman, 2015; Morton, 2019; etc), o al antiespecismo (Haraway, 2017, 2019b; Braidotti, 2015, 2018; etc), entre otras, dejo de lado a las visiones transhumanistas ejemplarmente sintetizadas en la Declaración Transhumanista redactada en 1998 y readaptada para su adopción por el consejo de editores de Humanity+ en marzo de 2009. ${ }^{3}$

Esto se debe a que inscribo mi propuesta en aquel posthumanismo filosófico que desarticula las jerarquías ontológicas heredadas del humanismo moderno y efectúa un giro crítico respecto de la visión de lo humano como especie excepcional, descentrando así al anthropos, y desmoronando a la división entre sujeto (de conocimiento) y objeto (de estudio) como algo presupuesto, previamente establecido. Por su carácter eminentemente transdiciplinar, el posthumanismo parece el marco de pensamiento adecuado para abordar cómo ciertos desajustes y reajustes en las relaciones entre cuerpo e imagen, entre imagen del cuerpo e imagen de lo humano, e incluso entre imagen del cuerpo (cierto orden representativo de lo corporal) y cuerpo de la imagen (el espesor matérico de la imagen y su capacidad agencial), son modulados en aquellas zonas de las artes visuales que se ven convocadas por los saberes científicos y las mediaciones tecnológicas.

En este sentido, el concepto de encuerpamiento que a continuación desarrollo, se muestra particularmente útil para el análisis de este tipo de producciones - del cual, en efecto, surge; por más que en este escrito aparezcan unas pocas obras y con un fin ilustrativo-. Me interesan este tipo de producciones artísticas entre las que destacaré algunas provenientes de mi país, Argentina - no sólo porque en ellas se evidencian las nuevas posibilidades expresivas que la ciencia y la tecnología han incorporado a la esfera artística con sus potencias de intervención —real o imaginariasobre la materialidad visual del cuerpo; sino también porque se trata de un terreno estratégico donde visualizar los reajustes contemporáneos en las iconografías corporales, para las cuales el concepto tradicional de

3 El transhumanismo no ha sido permeado por el antihumanismo posestructuralista, ni comulga con las críticas al excepcionalismo humano y su centralidad epistemológica realizadas por el posthumanismo filosófico. En tanto su programa se dirige a corregir, optimizar y aumentar las capacidades humanas mediante la intervención científico-tecnológica, sin tocar la ordenación ontológica de lo humano respecto de sus "otrxs", el mismo ha sido caracterizado como "ultrahumanismo" (Onishi, 2011) y como "neohumanismo" (Braidotti, 2018). 
cuerpo -y sus reactualizaciones contemporáneaspareciera inadecuado.

\section{Cuerpo e imagen: más allá de la identidad autocentrada}

La pregunta por el cuerpo y los modos de concebirlo, evocarlo y usarlo ha sido una constante del hacer y del pensar en el arte contemporáneo. En sintonía con la crisis del concepto de representación que se generalizó desde la segunda posguerra, y en el marco del proceso de desmaterialización de la obra de arte que aconteció desde los años '60, Ixs artistas comenzaron a producir nuevos acercamientos al cuerpo que, lejos de reducirlo a referente temático de la obra, lo introdujeron también como medio y herramienta creativa. Un ya clásico libro de Simón Marchán Fiz (1994 [1986]) sistematizó cómo, en aquellos años, emergieron lineamientos artísticos en los que el nivel teórico de la obra comenzó a prevalecer sobre el objetual, pero también en los que la acción empezó a ser explorada como un medio vivencial de expresión. Anna María Guasch en El arte último del siglo XX (2005), también ha dado cuenta acerca de cómo por aquella época surgen de forma simultánea en distintas latitudes las primeras experiencias de arte corporal o body art. En tal contexto, movimientos como fluxus, los accionismos y el happening dieron un paso contundente en dirección a una concepción del cuerpo en tanto agente y soporte de experiencias físicas, psíquicas y vitales. A su vez, frecuentemente convocaron al público (y sus cuerpos) mediante la provocación de las convenciones sociales y estéticas, así como también mediante su llamado a la participación activa.

Iván Mejía (2005), ha señalado que los primeros antecedentes de lo que será una visión posthumana del cuerpo en el arte tuvieron lugar en los marcos productivos de estos movimientos de los años ‘60 y ‘70. De acuerdo a su planteo, es fundamentalmente con el accionismo vienés y su programa de utilizar el cuerpo como soporte material de vivencias radicales de degradación y vejación (aunque también con otras formas menos truculentas del body art y del happening) que "el cuerpo real -ya no representado- es introducido en el discurso del arte como material, marco y fin de una experiencia" (Mejía, 2005, p. 37). Se empiezan a sentar así, por entonces, las bases de una concepción del cuerpo como algo moldeable, dispuesto a la manipulación, de la que se servirán luego los artistas tecno-científicos contemporáneos. Cabe señalar que esta hipótesis no pareciera quitarse el lastre de la división cartesiana entre el cuerpo y el sujeto, como si el primero fuera una propiedad del segundo.

Aun así, con los avances tecno-científicos que han acontecido desde entonces, las iconografías corporales se han desanclado de la referencia al modelo antropomórfico, en tanto la misma noción de cuerpo humano ha perdido sus contornos, por lo que no puede ser una mera unidad presupuesta sobre la cual efectuar el trabajo estético. El bioarte, el arte robótico, la generatividad programada, la realidad virtual y otras modalidades del quehacer artístico contemporáneo, intervienen y modulan materialidades e imaginaciones corporales que no pueden ser meramente reconocidas como cuerpos humanos. Como señala Hans Belting (2007, p. 109-110):

Cuanto más investigan el cuerpo la biología, la genética y las ciencias neurológicas, menos se nos ofrece éste como una imagen de fuerte carga simbólica. Tenemos ya en perspectiva la tentación de crear un nuevo ser humano, lo que no sólo significa educar a un nuevo ser humano, sino también inventar un cuerpo nuevo. Pero esta tentación, por su parte, es una manifestación del hecho de que hemos separado el cuerpo de la imagen tradicional del ser humano.

Ahora bien, ¿Cuál es esa imagen tradicional del ser humano, cifrada en una imagen del cuerpo, que según Hans Belting se ha descuajado? Según Rossi Braidotti (2015, s/p) el concepto de humano implícito en el humanismo (un sujeto de conocimiento autocentrado, el animal racional dotado de lenguaje) está representado ejemplarmente en el Hombre vitruviano, una "autocomplaciente imagen (...) que promueve comportamiento autocentrados (...) que distribuye diferencias sobre una escala jerárquica de decreciente dignidad (...) que a menudo justifica una relación violenta y beligerante con los otros sexualizados, racializados y naturalizados (...)". Sin embargo, en los cruces arte-ciencia-tecnología contemporáneos, esa imagen corporal anatómica que articula el concepto de sujeto humano durante la modalidad occidental, ya no pareciera constituir el modelo visual de referencia.

Desde ya, han existido otros acercamientos al cuerpo desde epistemologías que sin ser posthumanas se embarcaron en exploraciones no antinómicas de lo corporal. Resulta oportuno en este sentido remitir a Bajo los vestigios de un cuerpo: cultura, discurso, acontecimiento de la filósofa portugesa Eugénia Vilela (2009). Este ensayo repone que — como ya ha sido 
muy estudiado- bajo el régimen cultural, político y jurídico, cada discurso posee una imagen particular del cuerpo que lo constituye como objeto reconocible en su evidencia material. De tal modo, toda figura corporal puede discernirse mediante un análisis de las diversas formaciones de poder que lo acogen, organizadas según determinados regímenes de signos. Vale decir, en las modalidades disciplinarias y normalizadoras del discurso, todo cuerpo es significante, todo indicio del cuerpo es huella de una representación de él, en la que asimismo él se descubre. Por ello, la imagen del cuerpo es una construcción que revela los marcos culturales y epistemológicos en los que existe. Ahora bien, más allá de todo orden discursivo, la fuerza específica de lo corporal no sería la significación sino la intensidad (o, aún mejor, en plural: las intensidades).

Mientras las instituciones del lenguaje constituyen máquinas repetidoras de estereotipos corporales que normalizan su acontecer (o en términos deleuze-guattarianos: máquinas sobrecodificadora de cursos reterritorializados), el cuerpo es experiencia, gesto, resistencia a las significaciones legitimadas, movimiento; es decir: intensidad creadora. Ni puro canon de la lengua, ni pura excedencia irrepresentable: el cuerpo se afirma como un texto de placer, como intensidad de un sentido en plural. Según Vilela, el cuerpo es "una potencia simbólica creadora de sentido" (p.21), en tanto la intensidad del sentido ocurre precisamente como acontecimiento "entre las fronteras indefinidas de la piel de un cuerpo singular y de la piel del mundo" (p.17). De esta manera, la autora modula un pensamiento sobre lo corporal que lo presenta como la caja de resonancia de la textura del mundo (la cual, el mismo cuerpo compartiría). Debo admitir que me resulta imposible hacer justicia en este espacio a la sutileza de este análisis y la exquisitez de su escritura. Sin embargo, no puedo dejar de advertir que, para la Vilela (2009, p. 23):

(...) el cuerpo humano tiene una particularidad en relación con otros cuerpos: el carácter paradójico (...). Distinta de la contradicción, la paradoja supone una teoría del sentido. Habitan en nosotros los mismos espacios imposibles (...). El cuerpo es lo que fabrica, lo que produce, porque virtualmente es el lugar de la diferencia. En él coexisten espacios diferentes.

Vilela plantea una complejidad de lo corporal que transcurre poética y políticamente fuera del pensamiento dicotómico. Sin embargo, el orden de las jerarquías ontológicas pareciera el punto ciego donde permanece operativo un binomio fundante de la modernidad: la del animal humano respecto de la otredad no-humana. Según reitera: “El ser humano podría definirse, desde el ámbito antropológico, como el único ser capaz de ser habitado por otros seres o cosas" (p. 22), en tanto en el plano ontológico, su cuerpo es la materia prima de la expresión del mundo, el espacio de inmanencia en el que ocurre el sentido como acontecimiento. Según leo en su escrito, es la capacidad simbólica de crear sentido (la fuerza o el movimiento del decir que, sin reducirse meramente al logos, se articula en él por un roce con la materialidad del mundo) la que pareciera seguir distinguiendo al cuerpo humano de otros cuerpos existentes con los que compartiría una superficie ambigua, una continuidad saturada de fracturas. De tal modo, observo aún en su propuesta un sesgo textualista cuyo foco recae en la capacidad excepcional de lo sintiente, creadora de lo simbólico, propia de lo humano; pero además, este foco textualista no permite distinguir la dimensión estrictamente visual y específicamente material de la imagen, crucial para mi trabajo, interesado por los imaginarios corporales contemporáneos. De tal modo, en su abordaje existiría aún cierto sesgo propio de la tradición analítica y continental al que el realismo especulativo (Meillassoux, 2015; Harman, 2015) identifica como "correlacionismo": una tendencia a que el conocimiento del ser de los objetos siempre derive en la descripción implícita del acceso humano a ellos (lo que consistiría, en otros términos, en el prejuicio de considerar que la única vía de acceso a los objetos del mundo es que estén siempre ya correlacionados con un acto de pensamiento). A esto se podría sumar otro sesgo, asociado al anterior, consistente en concebir al cuerpo humano en los términos - abstractos - de individuos, de ente que, precisamente porque tiene la capacidad de apertura, es una unidad autocentrada en la que, en todo caso, "resuena" el mundo. Tal vez valga la pena el esfuerzo de especular acerca de la existencia de una intensidad y una lengua específica de las interacciones no-humanas entre los entes del mundo que aún no hemos aprendido, un sentido posthumano del que aún no somos capaces de participar, y que demandan el desafío de descentrar al anthropos.

En esta dirección, ya en 1983, mientras Donna Haraway redactaba su primer artículo escrito en computadora, el célebre Manifiesto para Cyborgs (1995), identificaba el desmoronamiento de tres fronteras que estructuraban las epistemologías modernas (aquellos saberes en los que se sostenía el concepto mismo de cuerpo, de humano, y de sujeto de conocimiento). La primera de ellas es la división entre lo humano y lo animal: se 
Imagen 1. (Stelarc, 1985). Amplified Body, Laser Eyes \& Third Hand, performance.

trata, en términos Agambenianos (2006 [2002]), del decaimiento de esa frontera que a lo largo de la historia occidental se ha establecido en la "máquina antropológica humanista", separando dos dominios para lo viviente: la vida y la nuda vida, o lo que Espósito (2006) estudió mediante los términos de bios (vida calificada) y zoé (vida indiferenciada). Esta división, organizó tradicionalmente los dos terrenos diferenciados a los que se abocaban, de un lado, las ciencias sociales, y del otro, las ciencias de la vida. Pero luego de que los avances en biotecnología borronearan las distinciones tajantes entre especies vivas, la construcción tales divisiones - organizadoras también de órdenes políticos de los cuerpos - parece haberse vuelto insostenible.

En segunda instancia, Haraway señalaba la porosidad contemporánea entre lo orgánico y lo maquínico: si las máquinas precibernéticas reproducían el sueño masculinista de creación de una suerte de doble defectuoso, de una caricatura de lo humano esperando a ser animada, las máquinas contemporáneas han conseguido un grado de autonomía, automatismo e inteligencia que disputan

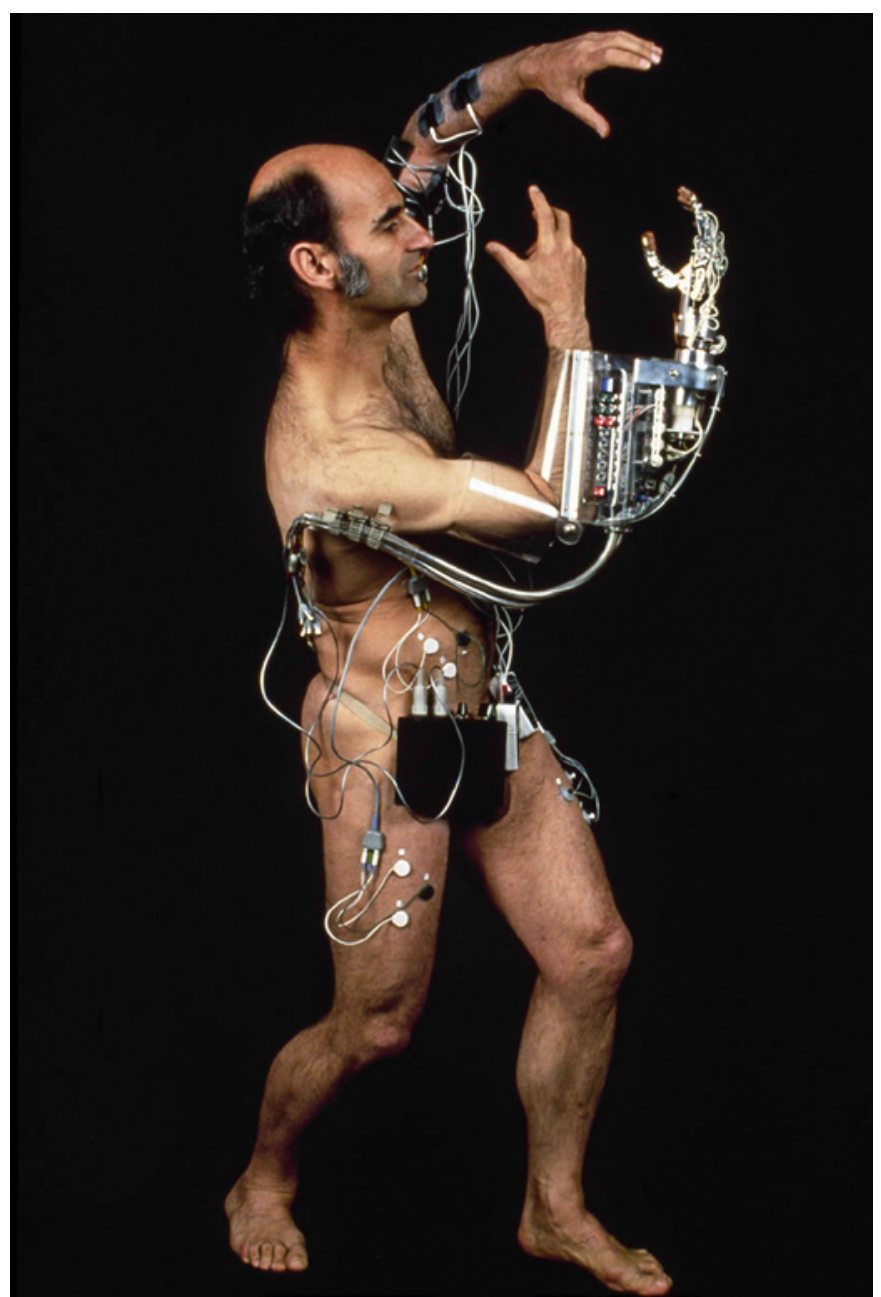

ciertas zonas tradicionalmente específicas de lo humano, volviéndose inquietantemente vivas. Por último, la tercera zona de deslinde que Haraway señalaba, se establece entre lo físico y lo no físico: por efecto de la miniaturización, las máquinas se distribuyen cada vez más en todos lados a la vez que se vuelven invisibles. No sólo móviles, portátiles, sino ubicuas, casi inmateriales. Vale pensar, en este sentido, en esas "materialidades vibrantes" (Bennet, 2010) que los nuevos materialismos destacan: electrones, cómputos, y minerales que "conducen" energía e información en circuitos integrados, entre otros. Se trata de una visión informática del mundo, en el que el trabajo ya no es efectuado por músculos y mecanismos, sino por materia informada a la que vale reconocerle su capacidad de agencia.

Con estos desajustes, no sólo las distinciones ontológicas de la epistemología occidental (el sujeto de conocimiento humano como algo autocentrado y específicamente delimitado, frente a sus "objetos", siempre presupuestos, siempre ahí yacentes para su descubrimiento y estudio) se han perdido. Como el concepto 


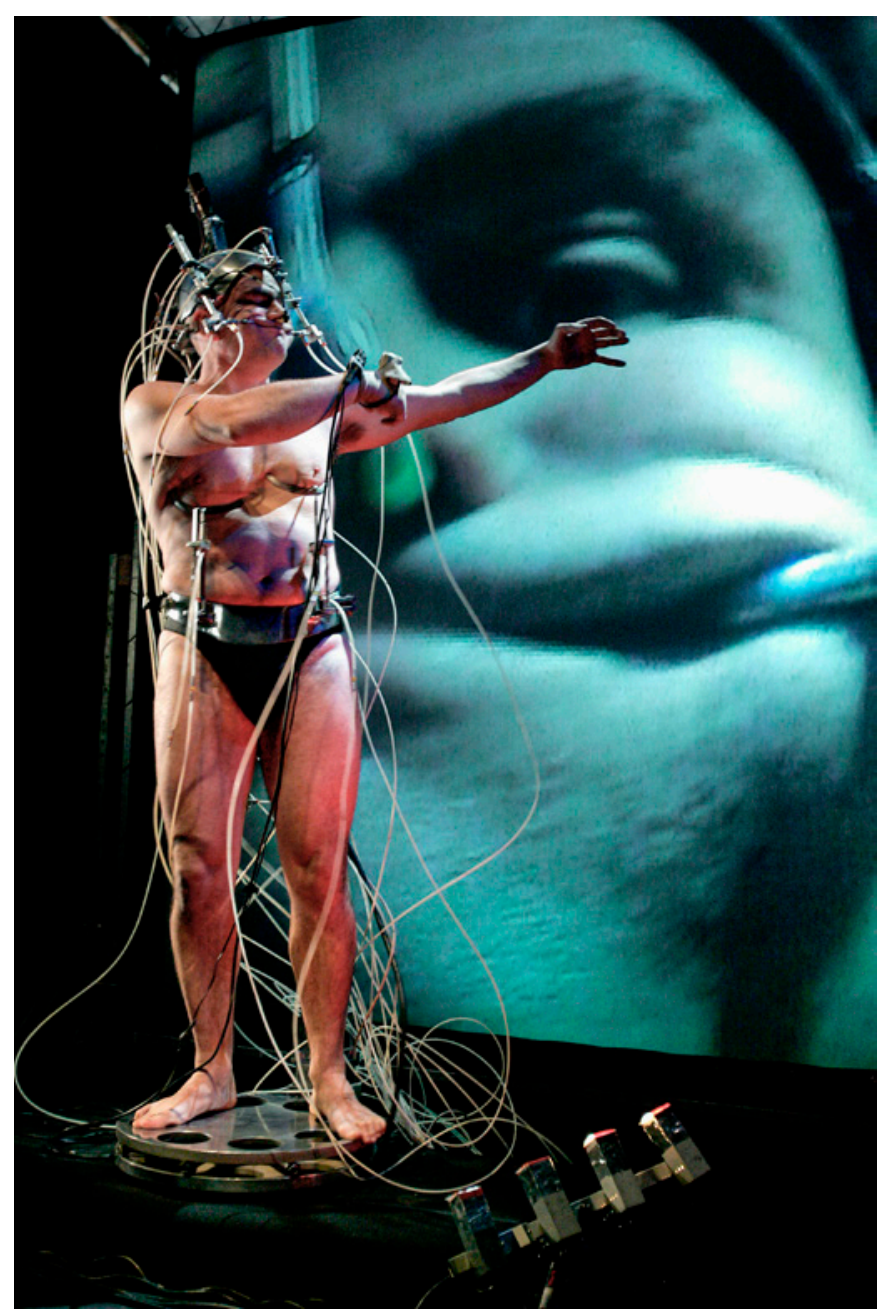

Imagen 2. (Marcel.lí Antúnez Roca, 1994). Epizoo, Performance interactiva.

mismo de cyborg proponía, también el cuerpo debe ser pensado como un ensamblaje de componentes orgánicos y maquínicos, humanos y animales, físicos y no físicos, una fusión barroca imposible de ser pensada en los términos de los dualismos modernos.

Aún así, la figura del cyborg parece haber cristalizado en la cultura visual contemporánea en una imagen profundamente antropocentrada, en la que los valores del humanismo moderno, lejos de desajustarse para plantear relaciones de contaminación con "sus otros", parecieran reforzarse en un upgrade por vía científico-tecnológica. ${ }^{4}$ Como la misma Haraway señala, "como figura combativa el cíborg ha tenido una corta vida"

$4 \quad$ Vale referir al respecto a la cinematografía de David Cronenberg, en la que la relación del cuerpo con las prótesis tecnológicas es problematizada en una tensión entre el imaginario de la extensión y de la amputación, como también así saturada de carga sensual. Esto es lo que plantea Rodríguez Ahumada (2014) en su análisis de Crash (2016), para el cual utiliza la figura del cyborg en asociación con la noción de monstruosidad. Según la autora, en dicha película lo que se pondría de manifiesto es una nueva experiencia (2019a, p. 292), en el sentido de que pareciera haber perdido su potencia emancipatoria para pasar a constituir una figura mainstream, canónica, en los imaginarios sociales contemporáneos. De esta forma, si la figura del cyborg aún sirve para pensar la propuesta estética de artistas como Stelarc o Marcel.lí Antúnez Roca, que encuadran sus programas creativos en imaginarios visuales transhumanos vinculados a los cuerpos mejorados del avatar, el replicante o robocop, en cambio ya no pareciera una figura adecuada para pensar, no sólo la heterogeneidad constitutiva de lo "propiamente" humano (es decir, los rasgos corporales no hegemónicos: femeninos, racializados, gordos, transexuales, etc) sino también su condición profundamente abierta, híbrida, interpenetrada con lo no-humano.

Vale decir, la contemporaneidad pareciera exigir de otras categorías analíticas que permitan percibir la emergencia de nuevas imágenes corporales (no

corporal y subjetiva contemporánea basada en un "entramado de auto-extensión que permite la inclusión de un yo diferente, un otro con el que mezclarse" (2014, p. 115). 
imaginarios instituidos, sino potencias instituyentes de lo imaginario), para seguir reflexionando sobre lo humano desde un espacio donde éste quede descentrado: para poder dar cuenta de dinámicas que trascienden su escala y que, incluso escapando de su aparato sensoperceptivo, no dejan de influir e interactuar en él.

\section{Encuerpamientos}

El análisis que propone Foucault del disciplinamiento de los cuerpos hoy ya parece anticuado (sin mencionar el hecho de que es intrínsecamente androcéntrico).

(...) los diagramas del poder foucaultiano describen lo que ya hemos dejado de ser; como toda cartografía, funcionan a posteriori. Braidotti, Sujetos Nómades.

Donna Haraway (1995 y 1999) desarrolló —según ella misma explicita, en base a la noción de "aparato de producción literaria" de Katie King - el concepto de "aparato de producción corporal" para dar cuenta de que los organismos en tanto encarnaciones técnico-naturales, actores semiótico-materiales y objetos de conocimiento, no preexisten a un supuesto instrumento que adecuadamente permita descubrirlo y conocerlo (pues no tienen una presencia inmediata ni una determinación final o única), sino que tienen una parte activa, emergiendo entre prácticas y actores. Según precisa:

Los cuerpos como objetos de conocimiento son nudos generativos semiótico-materiales. Sus fronteras se materializan en la interacción social entre humanos y no-humanos, incluidas las máquinas y otros instrumentos que median los intercambios en interfaces cruciales y que funcionan como delegados de las funciones y propósitos de otros actores. (...) Los 'objetos', al igual que los cuerpos, no preexisten como tales. (...) La localización/ observación de tales entidades no supone un descubrimiento desapasionado, sino que implica una estructuración mutua y normalmente desigual, correr riesgos, delegar competencias. (Haraway, 1999, p. 124)

En estas órbitas Harawayianas gravita la noción clave de este escrito. El encuerpamiento se ofrece, en primera instancia, como un concepto de alta operatividad teórico-metodológica a los fines de captar una imagen contemporánea del cuerpo que se expone móvil, porosa, abierta, deviniendo-con en el encuentro con otrxs (humanos y no humanos, materialidades vivas e inertes) en el pleno proceso de su transformación, en la circunstancia misma de su contingencia. Es así una formación material de lo visual — pues la diferencia entre forma y contenido, y entre imagen y materia no existe aquí- en la que, en cada caso específico, (re) presentar el cuerpo y su imagen por medio no de abstractos universales o referentes presupuestos - como el cuerpo antropomórfico del humanismo modernosino de ejemplos concretos, reales, tangibles en los que el mismo imaginario del cuerpo se modula. ${ }^{5}$

En este sentido, la noción visibiliza lo múltiple: lo que hay, hoy, son encuerpamientos diversos, polimorfos, proliferantes. Pero a la vez, la categoría implica captar lo singular: en cada caso de estudio hay un encuerpamiento, no un modelo teórico de corporalidad. En consecuencia, lejos de toparse con una imagen trascendental y universal del cuerpo, el concepto ilumina, cada vez, una "versión fidedigna" de casos de estudio particulares, específicos, reales, localizados, es decir, se encuentra con una "objetividad encarnada" para producir "saberes situados" (Haraway, 1995) acerca de los imaginarios del cuerpo en los cruces entre arte, ciencia y tecnología. Así pues, el encuerpamiento puede ser pensado como una óptica (es decir, una política visual para objetivar una porción del mundo), pero una de carácter táctil. Vale decir, el encuerpamiento es un cuerpo que se produce en la realidad concreta de su imagen, sobre la que también actúa (con otrxs agentes semiótico-materiales que tienen su agencia, y con los cuales se produce un roce, una afectación, un encuentro), encuerpando.

Es importarte destacar que el concepto de encuerpamiento se ofrece para pensar la imagen del cuerpo según una lógica no basada en la identidad. Según aprendí de Haraway, la identificación presupone al ente que identifica. Pero ya el posestructuralismo, los feminismos y el pensamiento decolonial nos han dado motivos para desconfiar de cualquier criterio esencial para la identificación. En cambio, el encuerpamiento constituye una imagen corporal que no precede a la relacionalidad que le es constitutiva y de la cual surge, en cualquier escala espacial o temporal en la que se da un ensamblaje, un encuentro material relativamente estable.

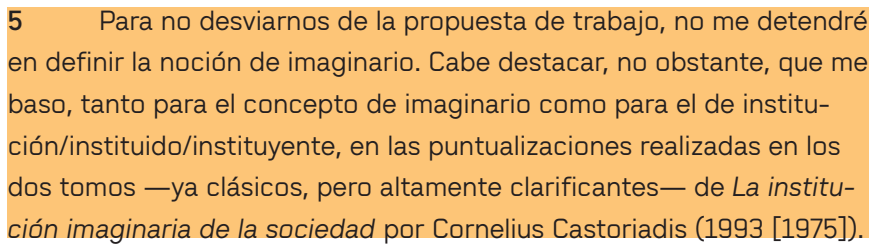




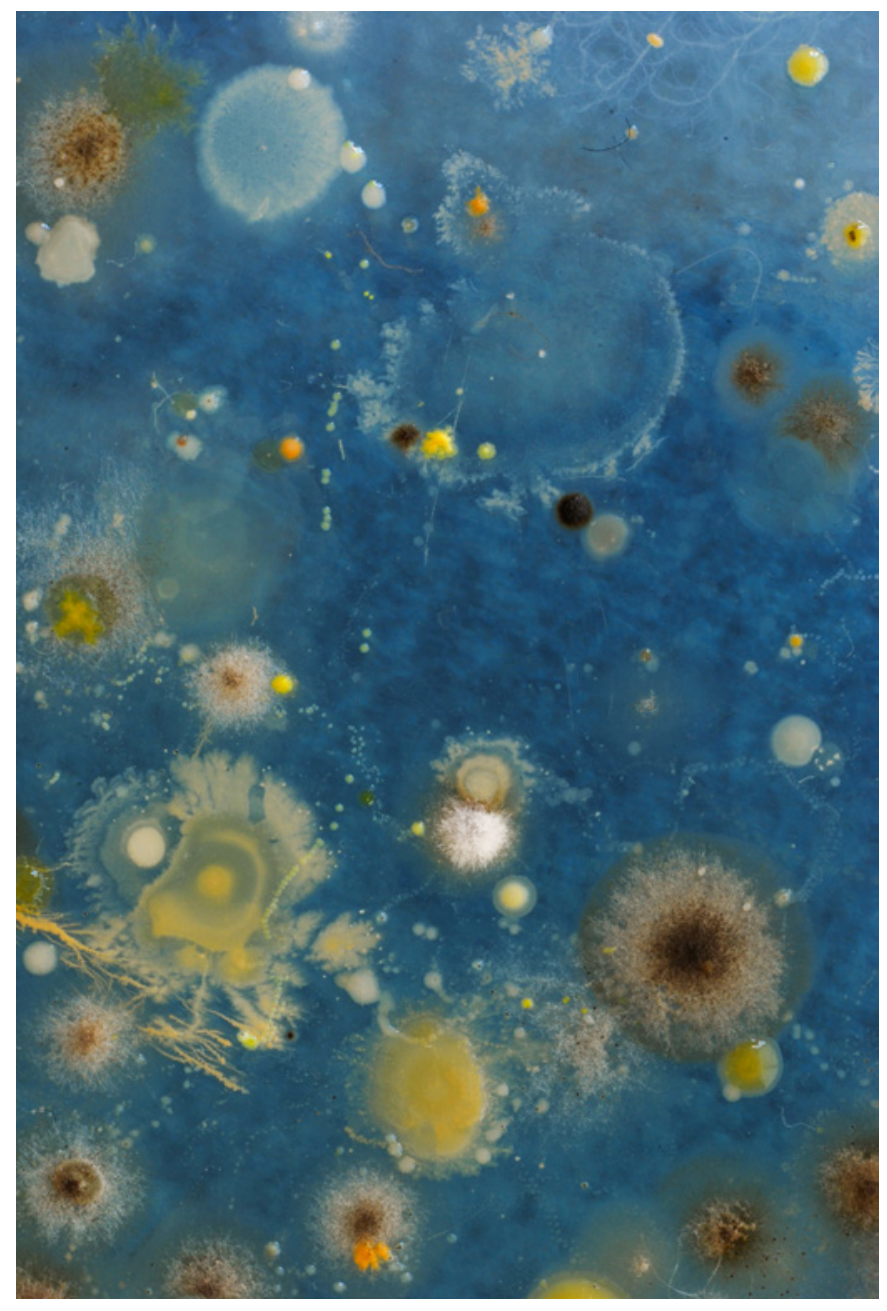

Imagen 3. (Luciana Paoletti, 2010-actualidad) "Eugenia", Serie Retratos.

Tomemos el caso de la serie Retratos (2010-actualidad) de la argentina Luciana Paoletti. Para realizarla, la artista toma muestras de los microorganismos que anidan en los cuerpos de los seres queridos, los cultiva, y fija un instante del crecimiento de estas colonias de bacterias y hongos en una imagen fotográfica. ¿De qué manera reconocer los "cuerpos" a los que estas imágenes "retratísticas" refieren? Pareciera que, lejos de confirmar la relación de semejanza con su modelo humano al cual representarían, estas imágenes abstractas y coloridas juegan con las porosidades del cuerpo humano retratado en base a la vida microbiológica que en él se desarrolla. Ejercita, así “La fenomenología del encuentro con un ser ecológico" (Morton 2019, 102), expone esa dimensión en la que el estatus ontológico del cuerpo humano se vuelve por lo menos impreciso, demasiado poroso: ¿dónde empieza y dónde termina la ecología del cuerpo humano, qué límite establecen sus

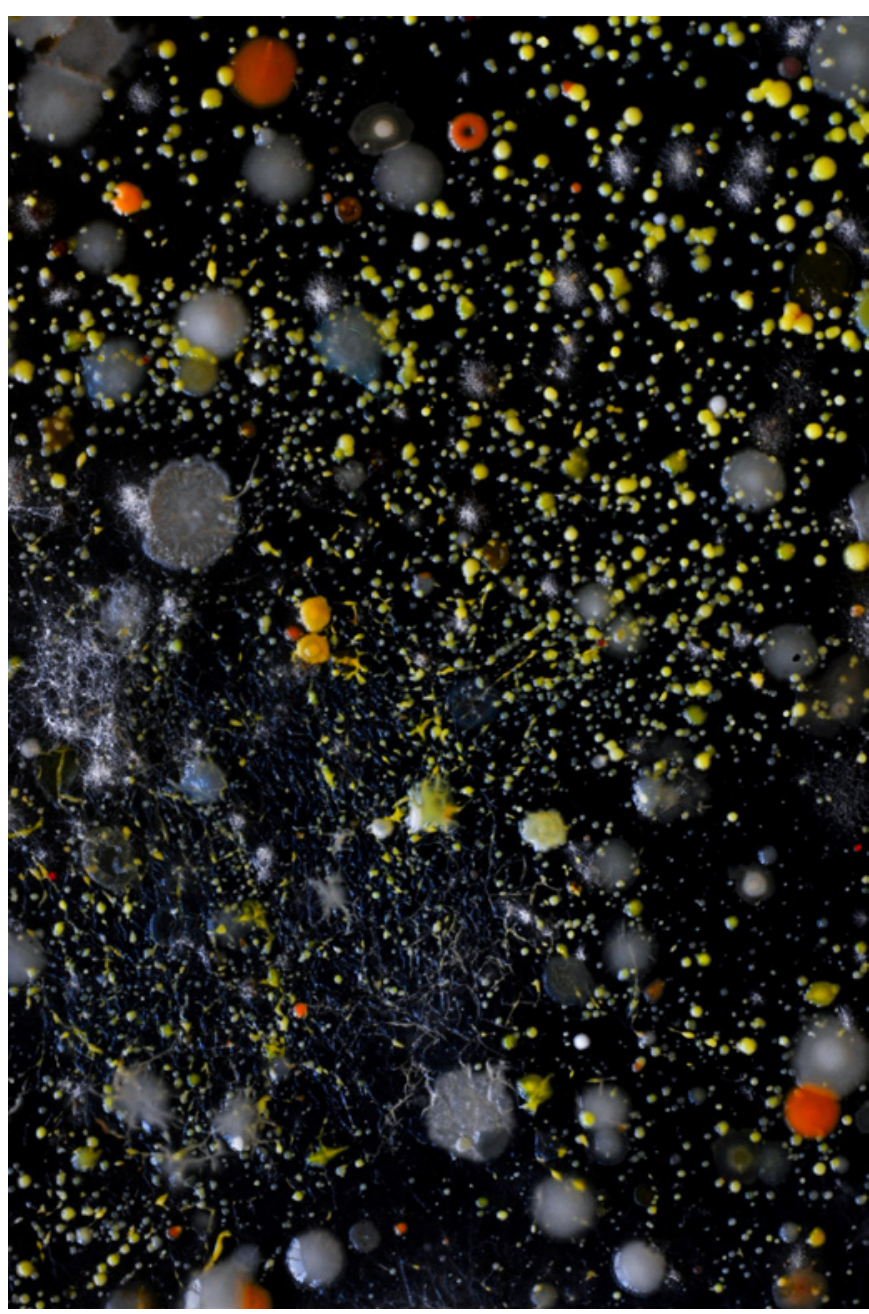

Imagen 4. (Luciana Paoletti, 2010-actualidad) "Autoretrato", Serie Retratos.

relaciones simpoiéticas ${ }^{6}$ ? Esta serie pareciera exponer el "Real simbiótico", esa simbiosis ecológica de partes humanas y no humanas de la que habla Timothy Morton, esa zona de encuentro y confusión con "algo que no soy yo de tal manera que incluso si este ser es obviamente parte de mí (...) no lo experimento como parte del supuesto todo que 'me' compone" (Morton 2019, 102-103). Zonas de desplazamientos, filtraciones, imprecisiones, acoplamientos: no meramente cuerpos, sino encuerpamientos.

\footnotetext{
6 Tomo este término de Donna Haraway (2019b), quien a su vez lo retoma de los desarrollos en biología efectuados por Beth Dempster y por el seguidor de Lynn Margulis, Scott Gibert. Se trata de un concepto que discute la noción de autopoiesis acuñada por Maturana y Varela (2003), que señalaba la capacidad autoorganizativa, la agencialidad individual de los sistemas cerrados; es decir, la producción continua de sí mismos. A diferencia de esta noción, la simpoiesis abandona el pensamiento centrado en unidades, entidades o seres individuales, para enfatizar en las dinámicas co-productivas, co-generativas, en las que las que más que "entes" se producirían "holoentes", ensamblajes simbióticos desplegados mutuamente, en devenires-con.
} 
Pareciera distinto, en este sentido, el reconocido proyecto A genomic Portrait: Sir. John Sulston (2001) de Marc Quinn, esa representación visual que, también de apariencia abstracta, contiene las instrucciones biológicas para rehacer el cuerpo del modelo retratado: el detalle del genoma. La propuesta conceptual de esta obra se dirige a problematizar la identidad única que porta el ADN de cada individuo: señala la existencia - potencial - de una imagen exacta del cuerpo de referencia. De tal modo, en esta obra la imagen (el cuerpo de la imagen) quedará adherida, fijada a la referencia al cuerpo humano del modelo, poniendo en actuación la lógica identitaria, la confirmación de la capacidad reproductiva de las relaciones entre cuerpo e imagen. Aquí hay, entonces, cuerpo: la imagen modélica -la aportada, hoy, por la genética- del cuerpo contemporáneo: su reproducción, la dinámica auto-generativa de la lógica identitaria. En cambio, lejos de la noción de identidad, lejos de una imagen refleja en la que el cuerpo vuelva en cada aparición a parecerse a sí mismo (o a (re)producirse en una copia, es decir, a clonarse), el encuerpamiento es un acto creativo, generativo, difractario, que permite percibir las fracturas, difuminaciones y desplazamientos que hoy experimenta el cuerpo y su imagen. Mientras la propuesta visual de Quinn nos habla de las dinámicas autopoiéticas del cuerpo humano, la de Paoletti nos habla de las dinámicas simpoéticas, del devenir-con otros en los que el encuerpamiento se efectúa. Por su carácter analítico, es el concepto de encuerpamiento el que permite establecer estas sutiles diferencias.
Es preciso reconocer, en este punto, que el encuerpamiento recibe las influencias ejercidas por el concepto de dispositivo que Foucault desarrolla a lo largo de su trabajo. En efecto, los encuerpamientos pueden ser pensados como formaciones estratégicas con funciones concretas y situadas, inscriptas en relaciones de poder y saber (podrían, en efecto, ser pensados como "dispositivos corporales"). Sin embargo, la estrategia foucaultiana está especialmente concentrada en el conjunto de instituciones, procesos de subjetivación y reglas en que se concretan las relaciones de poder-saber (Agamben 2014). En cambio, los encuerpamientos están concentrados en las modulaciones de los cuerpos y sus imaginarios que, si bien atravesados por el poder-saber, poseen una capacidad creativa e imaginativa, no sólo instituida sino también instituyente (no sólo reproductiva sino también productiva), en las dinámicas semiótico-materiales en las que se da cada vez. La noción permite, así, observar desvíos al poder no basados en la idea de resistencia sino en la de generatividad (de alguna manera, "empodera" al cuerpo no sólo como producto del (bio)poder sino como productor de potencias significativas y agente material). Si Gilles Deleuze (1990) puntualizó al dispositivo como madeja multilineal de fuerzas (quebradas y sometidas a derivaciones) de poder, saber y subjetividad, cuyas fibras no sólo conforman cada dispositivo y sus curvas de objetivación, sino que también los atraviesan y los fisuran, los bifurcan trazando tangentes con otros dispositivos, los encuerpamientos consideran también esos espacios "vacíos" que la "red", el "ovillo" o el "tejido" no captura:

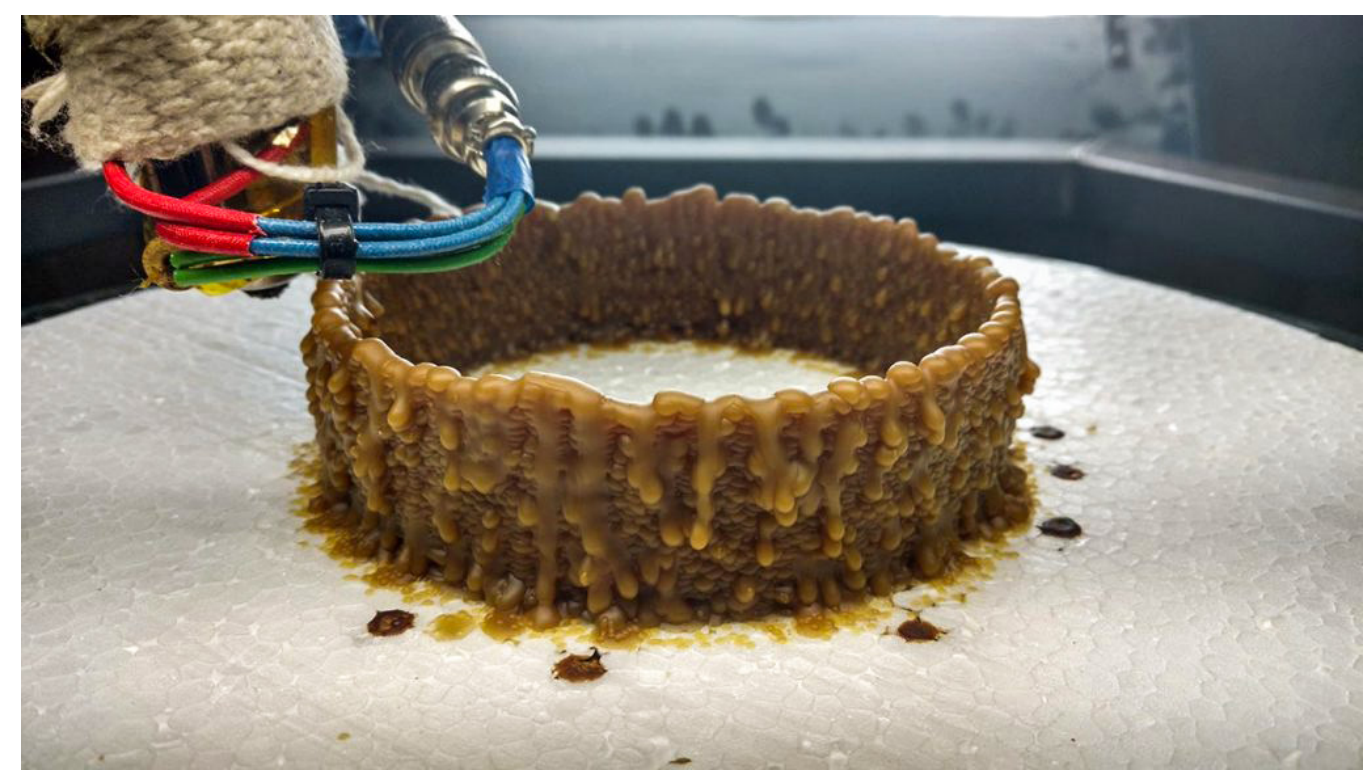

Imagen 5. (Juan Pablo Ferlat, 2008-actualidad) Detalle del proceso productivo de Perpetuum Golem. 


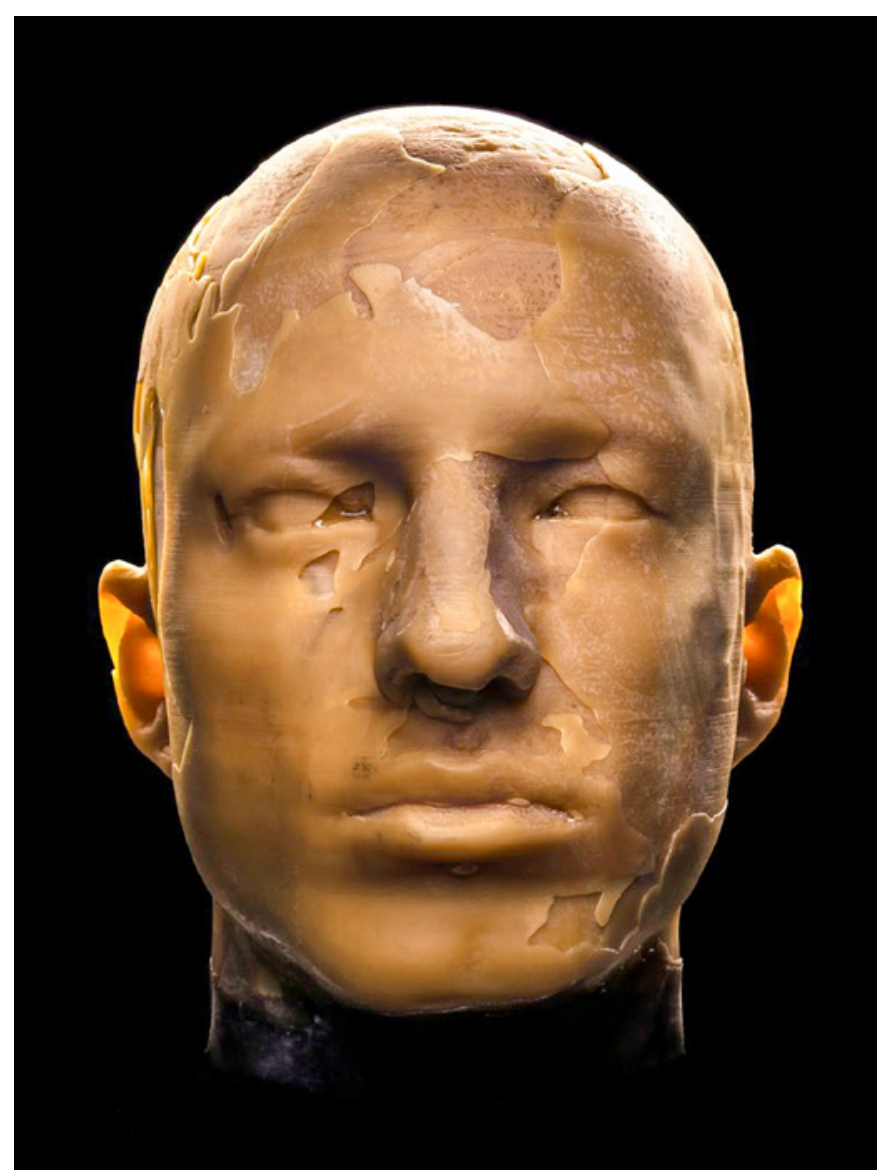

Imagen 6. (Juan Pablo Ferlat, 2008-actualidad) Perpetuum Golem.

toda una dinámica profundamente material en la que se efectúan los agenciamientos no codificados.

Consideremos al respecto el ejemplo de Perpetuum Golem de Juan Pablo Ferlat. Se trata de una serie que el artista inicia en 2008 y aún se encuentra en desarrollo, en el que explora el autorretrato mediante un sistema ideado y construido ad hoc de impresión 3D con cera virgen de abejas. Las instrucciones generativas de la imagen, son siempre las mismas: aquella que reproduce las proporciones de su rostro que han sido previamente escaneadas. El circuito, por su parte, funciona de manera continua en un ciclo de reciclado: fabrica, derrite y vuelve a imprimir las esculturas. De tal forma, en la procesualidad artefactual en la que se generan los autoretratos, ese mismo y único modelo corporal se encuentra con las dinámicas materiales propias de la cera en relación con los accidentes del ambiente y de su roce con la máquina de impresión. La cera se calienta, se fluidifica, cae, se solidifica, de modo que talla, gota a gota, diversos accidentes que vuelven imposible la repetición del rostro en una imagen siempre igual a sí misma. Sobre la base de una misma instrucción, de un mismo modelo visual, la agencialidad material que interviene en el proceso, genera derretimientos, coagulaciones, fracturas, texturas, relieves, convexidades que dan su espesor expresivo, su propia singularidad, a cada pieza de la serie. Se trata así de una dinámica de arreglos mutuos en la que el cuerpo del artista se ve modificado, afectado, en su (re) producción en imagen, a través de una generatividad no del todo controlada.

Así entonces, los encuerpamientos son figuras corporales concretas (no modelos abstractos universalizantes) tramadas con hilos estéticos, filosóficos, políticos, biológicos y tecnológicos, entre otros, con sus filamentos, sus enmarañamientos y sus líneas de fuga. Pero también son la materia densa o evanescente, viva o inerte, caliente o fría que cuaja entre esas fibras y en las que tales fibras se espesan, se trenzan y desatan o dispersan. A esta altura, vale destacar que el encuerpamiento no es mera "encarnación". El concepto rehúye de toda asociación a la idea cristiana de verbo hecho carne. Aquí no hay lugar para separar cierto hálito poiético (verbo, alma, espíritu, cogito o información) de la materialidad del cuerpo (sobre todo, considerando que la materialidad del cuerpo no es siempre ni solamente carnal). El concepto plantea la inseparabilidad del cuerpo y su imagen: toda corporeidad se modula en un devenir-con, en un 
hacer-cuerpo con otros, en los que el encuerpar cobra consistencia como imagen. El encuerpamiento recupera así, para la teoría, una opción por el juego, por lo lúdico, por la imaginación. También recupera una preocupación fundamental por la materia (humana y no-humana) y sus agencias. Mientras la metáfora — demasiado informática- de la red o el ovillo propia del concepto de dispositivo corre el peligro de caer en una teoría de los significantes internamente diferenciados en el marco de un código o sistema a deconstruir, y mientras la idea de carnalidad se muestra aún dualista y demasiado asociada a la carnalidad animal, el encuerpamiento apuesta por un principio de generación limitado, contingente y afectado semiótico-materialmente que disloca a la imagen de su idealidad.

Aún así, vale subrayar que el encuerpamiento sabe lo que el poder hace, es decir: producir la realidad sobre la que se actúa (Foucault, 2008 [1976]). Por ello, evita reproducirlo. Si bien el encuerpamiento como herramienta teórico-metodológica apuesta por las posibilidades generativas que se ponen en juego en la posición analítica, también implica una atención estricta a las especificidades semiótico-materiales impuestas por el corpus de análisis. De tal modo, los encuerpamientos son estructuraciones mutuas entre corporeidad, imagen y pensamiento en la que todos ellos encuerpan (se instituyen provisoriamente, cuajan en una organización relativamente estable) en una imagen del cuerpo (una porción específica del imaginario contemporáneo del cuerpo) plausible, así, de ser discernida.

En consecuencia, en segunda instancia, se trata también de un concepto estratégico en términos políticos; quiero decir: no es fácilmente reterritorializado(ble $)^{7}$ o apropiado(ble) ${ }^{8}$. Esta es una dimensión fundamental del

7 Reponer el cuerpo de pensamiento desarrollado por Deleuze y
Guattari (2004 [1980]) es una empresa que excede los límites de una
nota al pie, al margen de que ya se ha convertido en una lectura ya
canónica. Aun así, vale aludir que el territorio, para estos autores, es
una construcción social resultado del juego de relaciones de poder,
atravesada tanto por el dominio molar de las representaciones como
por el dominio molecular de las creencias y los deseos. Si todo campo
social está animado por tensiones, intensidades, ritmicidades que
abren líneas de fuga definidas por movimientos de descodificación
y desterritorialización, también se producen sobrecodificaciones y
reterritorializaciones, líneas de objetivación que re-estabilizan y re-or-
ganizan las relaciones de poder.
8
Inappropiate/d Other. Special Issue on Third World Women editado
por Trinh T. Minh-ha (1986-1987). El término designaría la posición
histórica de aquellxs que, en las narrativas occidentales modernas
de la identidad, no adoptaron las máscaras del "yo" ni las del "otro",
de modo tal que tampoco quedan atrapadas en sus políticas de

encuerpamiento si se toma en cuenta que figuras de pensamiento propuestas como emancipatorias, como la del cyborg o el monstruo (Haraway, 1995, 1999, 2019a), han sido reterritorializadas; vale decir, han caído en las lógicas de la reproducción -y no de la generación- de pensamiento, confirmando en cada aparición marcos teóricos ya normalizados, que a veces combinan demasiado bien con las modas intelectuales y las lógicas disciplinarias de la gran maquinaria del poder sobrecodificador académico.

Un buen ejemplo para reflexionar sobre ello es la obra Lee Bul. Sus series escultóricas Monster (1998) - Cyborg (1998), como sus propios títulos proponen, resultan hibridaciones corporales que - siempre sin cabeza - involucran fragmentos vegetales, animales y maquínicos que parecen haber sido desmembrados y reensamblados. Karla Jasso (2008), basándose en una lectura realizada por Braidotti, las ha abordado mediante el concepto de cyborg como propuestas de crítica al modelo hegemónico de representación visual femenina como objeto de deseo, a la vez que como crítica al optimismo del futurismo corporal tecnológico (vale decir, a los discursos transhumanos). Ahora bien, si el cyborg emergió en el pensamiento de Haraway como figura política y retórica que auguraba la posibilidad de una reinvención mitológica de las identidades en clave feminista por vía tecnológica, sus potencias emancipatorias parecen haber sido inhibidas. Esto se ha efectuado mediante una fijación - que recorre toda la cultura visual contemporánea- de la idea de cyborg al imaginario transhumano, esos cuerpos humanoides perfeccionados según el modelo de máquina: cuerpos profundamente antropomórficos, mezcla de carne (por cierto, generalmente blanca) y metal, o cuerpos virtuales que, llevando al paroxismo la división cartesiana, se desentienden del cuerpo físico y vivencial (como hemos visto, en Robocop, replicantes, avatares, tanto como en el programa artístico de artistas como Stelarc o Marcel. lí Antúnez). Las lógicas del poder han reterritorializado la noción del cyborg, la han fijado a un modelo corporal normalizado: el del perfeccionamiento humano por vía tecno-científica (no por casualidad la misma Donna Haraway lo ha abandonado). En este sentido, el encuerpamiento pareciera menos reapropiable, menos

\footnotetext{
la dominación. Lxs otrxs inapropiadxs/inapropiables resistirían a ser encasilladxs en las taxonomías e inscriptas en los mapas de la diferencia normada. Haraway retoma este concepto para pensar al cyborg y al monstruo: dos figuras corporales/identitarias que, según entiendo, parecieran haber sido re-apropiadas (o, en términos deleuze-guattarianos, reterritorializadas).
} 


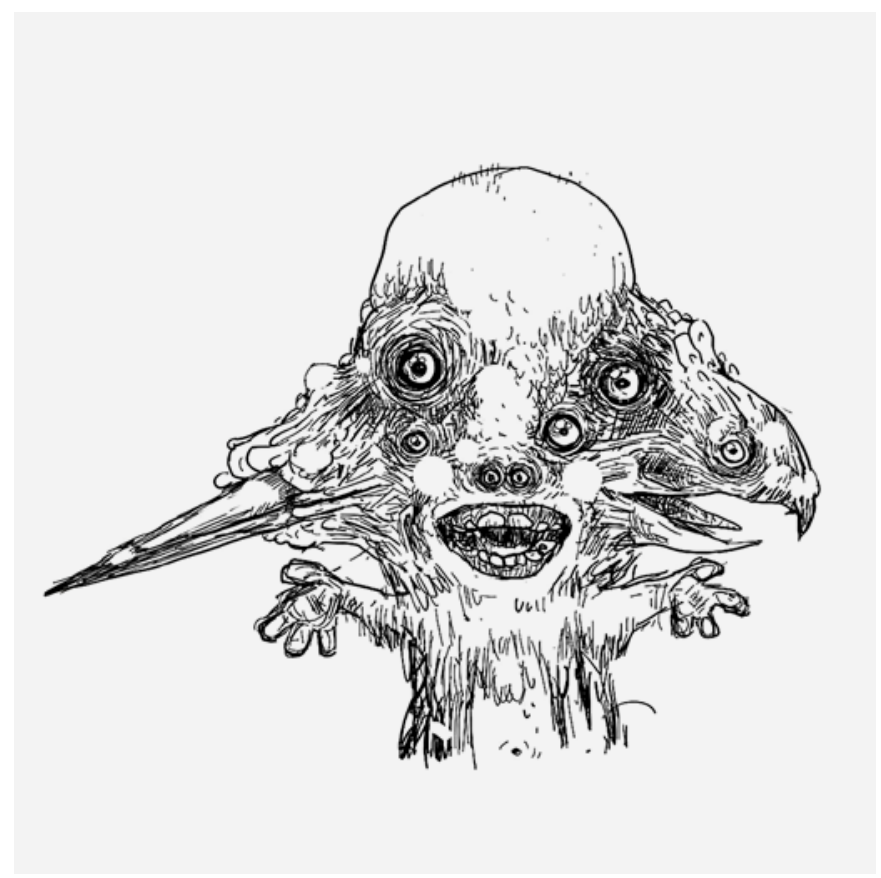

Imagen 7. (Mariano Giraud, s/f) Dibujo en tableta, S/T.

readaptable que dicho concepto (u otros similares) $)^{9}$ en

9 Las teorías feministas tienen ya una larga tradición en subvertir representaciones y conductas mediante la creación de figuraciones alternativas y ficciones políticas (como también así lo tuvo ejemplarmente el pensamiento deleuze-guattariano, por ejemplo, con la noción de rizoma). Rossi Braidotti (2000) propone -basándose en el pensamiento Deleuziano- una figura que provoca resonancias con el encuerpamiento: el sujeto nómade. Se trata de una figura teórica "conveniente para pensar la subjetividad contemporánea. (...) a fin de inventar nuevos marcos de organización, nuevas imágenes, nuevas formas de pensamiento" (Braidotti 2000, 26). Sin embargo, el nómade, como indica la autora, no tiene pasaportes o tiene muchos: lo que a mi modo de entender es algo lógico para el pensamiento de una autora del norte, que no necesita grandes esfuerzos para comprarse un ticket, atravesar fronteras y sortear los puestos de control. Pero - para una mirada enraizada en Latinoamérica y consciente de los aportes del pensamiento descolonial- la figura del nómade peca de ostentosa. Su resistencia a establecerse y a reconocer orígenes pareciera desestimar la centralidad de las señas de procedencia, esas marcas que el poder (entre ellos, el epistémico) imprime sobre los cuerpos (entre ellos, el teórico), y con los que los identifica, señala y normaliza/castiga. Por ello, los encuerpamientos exponen la condición concreta -las latitudes geográficas y el presente de las memoriasen la que ellos mismos se producen. Los encuerpamientos tienen lugar en un espacio particular, en el momento de detención donde un cuerpo/imagen toma una forma/contenido. Un encuerpamiento - si bien no reproduce totalmente- no puede sortear los (bio)poderes, no los desconoce. 0 en otras palabras: los análisis de obras de arte no pueden desconocer la existencia de fronteras estéticas (entre ellas, los cánones globales, regionales y locales del arte -y los estándares corporales normalizados-), además de políticas, tecnológicas, epistémicas y materiales que se imponen y que limitan las potencias emancipatorias del concepto. Un encuerpamiento ocurre siempre en

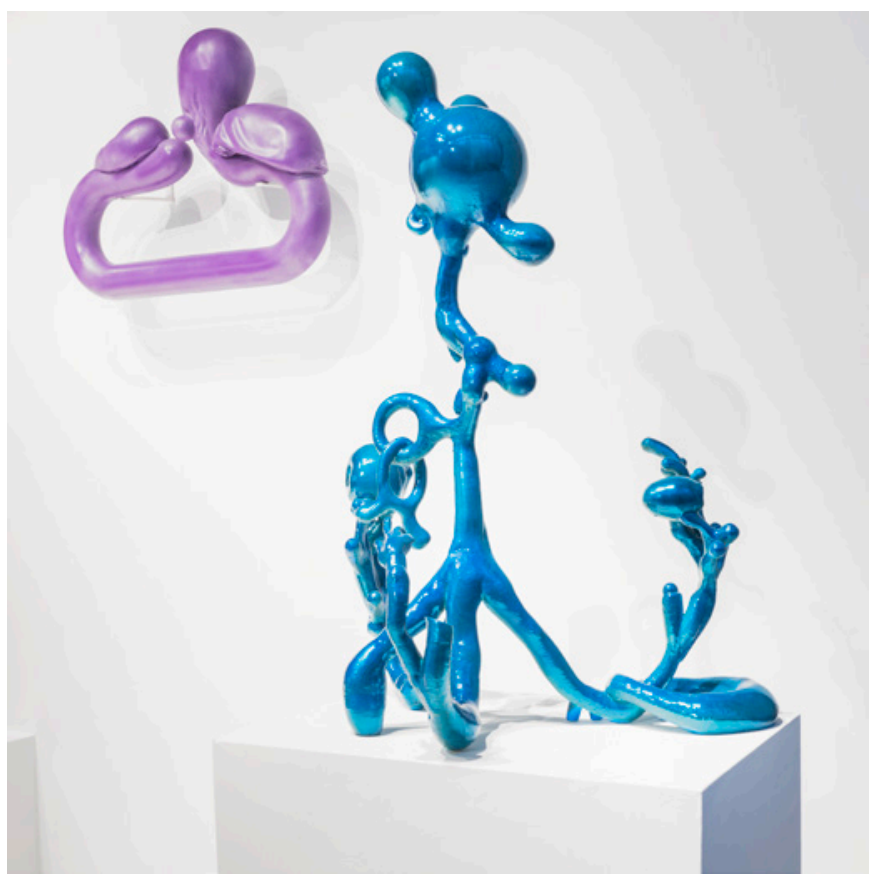

Imagen 8. (Mariano Giraud, 2018/9) Modelado digital e impresión 3D, $\mathrm{S} / \mathrm{T}$.

tanto no aporta una referencia formal nueva, no organiza una figura corporal estable, los encuerpamientos jamás caen en la lógica reproductiva del modelo.

En este sentido, al igual que la obra de Lee Bul, la del argentino Mariano Giraud puede ser mejor pensada mediante el concepto de encuerpamiento. Giraud en los últimos años ha sistematizado un proceso de trabajo que suele comenzar por el dibujo en tableta digital y su posterior traducción a la tridimensión mediante un programa de modelado digital, para una conversión a escultura mediante impresora 3D o a realidad virtual. Los encuerpamientos que emergen en sus trabajos, parecieran jugar con las posibilidades de imaginar violaciones de las leyes naturales, degeneraciones en los procesos de génesis y evolución orgánicas. Una excedencia de vida (entre lo animal —en especial lo anfibio-, lo vegetal y lo tecnológico) parece crecer, insumisa, anudando fuerzas y espaciamientos sobre sí misma. Concavidades y convexidades, plegamientos sobre sí, hacen emerger vísceras, órganos sexuales, orificios, viscosidades, protuberancias, tejidos, extremidades que se continúan hasta mutar, desafiando el orden funcional de los

la situación real donde matrices de poder y saber se cruzan, encontrando límites y negociaciones además de oportunidades creativas. Un encuerpamiento no es una figura de libertad y emancipación; más bien, es una articulación donde se dibuja una frontera, un contorno; es una modulación, un tono, una consistencia provisoria, o una tecnología visualizadora de figuraciones corporales precarias. 
cuerpos. Como si cada sector del cuerpo, como si cada órgano se abocara a una función diversa de la "propia", o como si las funciones se desplazaran a zonas incorrectas pero posibles, proponiendo nuevas potencias e intensidades, placeres y multiplicidades para su devenir. Sus encuerpamientos, desafían los parámetros del reconocimiento visual, poniendo en juego ciertos desajustes formales al ejercicio del poder sobre los cuerpos (o, en nuestros términos, a la fijación entre cuerpo de la imagen e imagen corporal).

En este sentido, la misma naturaleza conceptual del encuerpamiento es mutable, magmática: no asigna al cuerpo una forma, funcionalidades o contornos delimitados, una materialidad ni un significado preestablecido, por lo que lo vuelve algo difícil de ser capturado, asignado o sujetado a un aparato de poder normalizador, codificador o con pretenciones de trascendencia. Los encuerpamientos son, así, formaciones precarias y contingentes en las que se densifica, conglutina o solifica un encuentro exteriorizable entre un corpus visual y un pensamiento (es decir, un contacto en el que se vuelve discernible, objetivable, una imagen provisoria del cuerpo contemporáneo). Pero el encuerpamiento nunca se fija (ni a las formas, ni a las figuras, ni a las materias de esos cuerpos/imágenes, ni a las formas, ni las figuras, ni las materias con las que los pensamos). En consecuencia, se constituye en cada caso, manifestando alteridades, diferencias y desigualdades inscriptas en los cuerpos.

Así pues, por último, el encuerpamiento consiste en un concepto reversible: un encuerpamiento es la forma/ contenido semiótico-material que se genera entre el corpus teórico (el cuerpo analítico o del pensamiento) y el corpus de análisis (el cuerpo de la obra), entre la imagen del cuerpo (el orden representativo) y el cuerpo de la imagen (su materialidad), de modo tal que entren en una dinámica de arreglos y ajustes mutuos y provisorios.

En el encuerpamiento, el cuerpo no se identifica, no se reconoce ni se descubre (porque no se presupone): se modula. De este modo, el concepto permite también sortear el punto ciego en el que ha caído el concepto de representación. ${ }^{10}$ Vale decir, impulsa a no parali-

10 El concepto no sólo ha despertado largas discusiones en el
campo de la teoría estética y la crítica cultural desde mediados del
siglo XX, sino que también plantea interrogantes cruciales para la
ciencia y la tecnología (cómo representar el objeto de conocimiento,
con qué instrumentos abordarlos y percibirlos, mediante qué criterios
definir los esquemas para visualizarlos, etc), tal y como dan cuenta

zarnos en aquellos desajustes entre el objeto (o una realidad que ya no se percibe como ya dada, inerte y trascendente) y el signo (aquella imagen, texto u objeto semiótico-material que aparecería en su lugar, representándolo). Así, nos insta también en el plano de la investigación no sólo a describir y analizar, sino también a imaginar y crear, a arrojarnos también a proyectos de especulación teórica.

\section{Referencias}

Agamben, G. (2006 [2002]). Lo abierto. El hombre y el animal. Buenos Aires: Adriana Hidalgo.

(2014). Qué es un dispositivo. Buenos Aires: Adriana Hidalgo.

Belting, H. (2010 [2002]). Antropología de la imagen. Buenos Aires-Madrid: Katz.

Bennet, J. (2010). Vibrant matter. A political ecology of things. USA: Duke University Press.

Braidotti, R. (2015). Lo posthumano. Barcelona: Gedisa. (2000 [1994]). Sujetos nómades. Corporización y diferencia sexual en la teoría feminista contemporánea. Buenos Aires: Paidós.

(2018). "Post-Humanimals". Comunicación presentada en Dictionary of Now \#12, Haus der Kulturen der Welt (HKW) 100 Years of Now, Berlín, 24 de mayo. https://tinyurl.com/ujczkj8b

Coole, D. y Frost, S. (2010). "Introducing the New Materialisms", en New Materialisms. Ontology, Agency, and Politics. Durham-Londres: Duke University Press.

Castoriadis, C. (1993 [1975]). La institución imaginaria de la sociedad, tomos 1 y 2 . Buenos Aires: Tusquest Editories.

Deleuze, G. (1990). “¿Qué es un dispositivo?”. En: Foucault, filósofo. Argetina: Gedisa Editores.

Deleuze, G. y Guattari, F. (2004 [1980]). Mil Mesetas. Capitalismo y Esquizofrenia. Valencia: Pre-Textos.

trabajos de Bruno Latour (2012 [1991]), Don Ihde (2004) y Pablo Rodríguez (2019), sólo por referir a algunas perspectivas diferenciales del asunto. 
Espósito, R. (2006). Bios. Biopolítica y filosofía. Buenos Aires: Amorrortu.

Ferrando, F. (2019). Philosophial Posthumanism. New York: Bloomsbury Academic.

Foucault, M. (2008 [1976]) Historia de la Sexualidad, 1. La voluntad de Saber. Buenos Aires: Siglo XXI Editores.

Guasch, A. M. (2000). El arte último del siglo XX. Del posminimalismo a lo multicultural. Madrid: Alianza.

Haraway, D. (1991). Ciencia, cyborg y mujeres. La reinvención de la naturaleza. Valencia: Cátedra.

. (1999a). “Las promesas de los monstruos: una política regeneradora para otros inapropiados/ bles". Política y Sociedad, (30), 121-164.

https://tinyurl.com/yf72pm77

(2019a). “Cíborgs, coyotes y perros. Una

familia de figuraciones feministas (entrevista)", en Las promesas de los monstruos. Ensayos sobre ciencia, naturaleza y otros inadaptables. Salamanca: Holobionte.

(2019b). Seguir con el problema. Generar parentesco en el Chthuluceno. Bilbao: Consonni.

Harman, G. (2015). Hacia el realismo especulativo. Ensayos y conferencias. Buenos Aires: Caja Negra.

Ihde, D. (2004). Los cuerpos en la tecnología. Nuevas Tecnologías: nuevas ideas acerca de nuestro cuerpo. Barcelona: UOC.

Jasso, K. (2008). Arte, tecnología y feminismo: nuevas figuraciones simbólicas. México: Universidad Iberoamericana.

Maturana, H. y Varela, F. (2003 [1994]). De máquinas y seres vivos. Autopoiesis: la organización de lo vivo. Buenos Aires: Lumen.

Marchán Fiz, S. (1994 [1986]). Del arte objetual al arte de concepto. Madrid: Akal.

Meillassoux, Q. (2015). Después de la finitude. Ensayo sobre la necesidad de la contingencia. Buenos Aires: Caja negra.

Mejía, I. (2005). El cuerpo post-humano en el arte y la cultura contemporánea. México: UNAM.
Minh-ha, T. T. (Ed.). (1986-1987). She, the Inappropiate/d Other. Special Issue of Third World Women. Discourse, 8 (Fall-Winter).

https://tinyurl.com/adswjsjf

More, M., Vita-More, N., Bostrom, N. et al. (2009 [1998]). Declaración Transhumanista.

https://tinyurl.com/4uc75fuu

Morton, T. (2019). Humanidad. Solidaridad con los no-humanos. Buenos Aires: Adirana Hidalgo.

Latour, B. (2012 [1991]). Nunca fuimos modernos: ensayo de antropología simétrica. Buenos Aires: Siglo XXI.

Onishi, B. (2011). "Information, bodies and Heidegger: tracing visions of the posthuman", en SOPHIA, 50(01). Doi 10.1007/s11841-010-0214-4

Rodríguez, P. 2019. Las palabras en las cosas. Saber, poder y subjetivación entre algoritmos y biomoléculas. Buenos Aires: Cactus. Doi https://doi.org/10.14483/ udistrital.jour.c14.2014.2.a08

Rodríguez Ahumada, J. (2014). “David Croenenberg y el cuerpo abierto". Calle 14, 9 (14), 106-117. https://doi. org/10.14483/udistrital.jour.c14.2014.2.a08

Vilela, E. (2009). "Bajo los vestigios de un cuerpo: cultura, discurso y acontecimiento". Calle 14, 3 (3), 10-25. Doi https://doi.org/10.14483/21450706.1212 